\title{
Phrasal alternation in the Pondok Tinggi dialect of Kerinci An intergenerational analysis
}

\author{
ERNANDA \\ Untu? Pa? Hein, yo dzaso diyan \\ cinto no pado baso kincai idzua? \\ lapau? kəno udzua, idzua? laka kəno panaeh. \\ 'To Hein, whose dedication and love for the \\ Kerinci language has never grown moldy in \\ dampness, nor been cracked by heat'.
}

\begin{abstract}
This paper examines the implications of language contact in a Malay sub-variety known as Pondok Tinggi, spoken in Sumatra. My focus is on the grammatical phenomenon of phrasal alternation. Phrasal alternation is characterized by the presence of two distinct forms for nearly all lexical items, whose final syllables differ in shape. These are termed absolute and oblique (Steinhauer and Usman 1978: 485). The intergenerational transmission of this uncommon feature offers a way to measure the degree of contact-induced language change in Pondok Tinggi. An experiment was conducted to elicit the usage of the absolute and the oblique forms in order to find out how the distribution of phrasal alternation has changed within the last two generations. I reveal a grammatical simplification caused by contact between Pondok Tinggi and Bahasa Indonesia, a related Malayic variety serving as Indonesia's prestigious official language. This adds a dimension of loss of local linguistic diversity to more familiar tropes of the national success of Bahasa Indonesia.

KEYWORDS

Phrasal alternation, Pondok Tinggi, Kerinci, intergenerational transmission.
\end{abstract}

\footnotetext{
ERNANDA is a PhD student at Leiden University Centre for Linguistics (LUCL). She has been granted a scholarship for her PhD research from the Netherlands Fellowship Programmes (NFP) by the Dutch Ministry of Foreign Affairs. She received her MA in Linguistics from Radboud University Nijmegen, The Netherlands in 2011. Ernanda may be contacted at: n.ernanda@hum. leidenuniv.nl.
}

C 2015 Faculty of Humanities, University of Indonesia 


\section{INTRODUCTION ${ }^{1}$}

Sumatra is the largest island in the western part of Indonesia and home to many local languages and dialects. Wurm (2003: 22) comments that:

[t]here are very few languages in Sumatra which would be likely targets for endangerment from Indonesian and/or large local languages. One language on one of the islands located off the south western coast of Sumatra is endangered. Another one on an island off the northeastern coast of Sumatra has been reported to be moribund, or even already extinct.

The phenomenon of language loss in Sumatra is partly caused by language contact, in which one language becomes more powerful and threatens other small and non-prestigious varieties.

In this paper, ${ }^{2}$ I will discuss intergenerational language loss in a Malayic sub-variety spoken in Sumatra called Pondok Tinggi (hereafter PT). Located in central Sumatra (Kerinci regency, Jambi Province), PT is the name of a village as well as the name of a dialect spoken there (see Map 1). The PT people tend to refer to it as a language rather than a dialect, namely the language of pundo? tingai, despite the fact that it is more appropriately referred to as a dialect belonging to Kerinci, one of the 700 odd regional languages of Indonesia. While a Malayic sub-variety, the PT dialect differs strikingly from other Malay varieties, as will be shown throughout this paper.

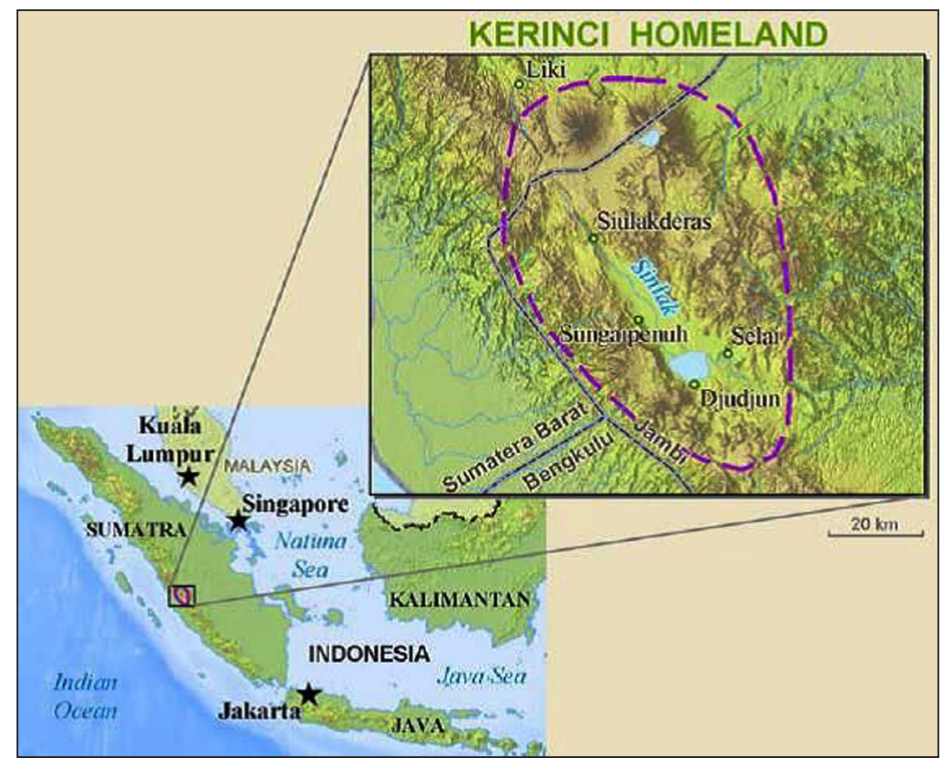

Map 1. Kerinci homeland.

1 I would like to thank Tom Hoogervorst for his invaluable feedback, assistance, and support. I also express my gratitude to Timothy Mckinnon and David Gil for their feedback and comments on an earlier version of this paper. Needless to say, I take full responsibility for any remaining errors or shortcomings. the article.

For the glosses and abbreviations see the list in "Abbreviations used" at the end of 
In PT, there is a complex language contact situation. PT, itself a Malayic sub-variety, is in contact with closely related languages, namely Indonesian (Bahasa Indonesia), Minangkabau and other Kerinci dialects. These varieties in contact have influenced PT in certain ways. This language contact situation is discussed in detail in the following section.

PT exhibits a unique morphophonological phenomenon known as phrasal alternation. The use of phrasal alternation among various age groups allows us to measure the degree of contact-induced language change. Phrasal alternation means that nearly all lexical items have at least two distinct forms differing in the shape of their final syllables. These two forms have been termed "absolute" (ABS) and "oblique" (OBL) by Steinhauer and Usman (1978: 485) in their description of the neighbouring dialect of Sungai Penuh. ${ }^{3}$ Most of the time, but not always, the absolute form is used in phrase final position and the oblique form is used in non-final position. Examples of phrasal alternation are shown below.
(1) umpau
tree.ABS
'Tree'
(2) umpun dzambeu
tree.OBL guava.ABS
'Guava tree'
(3) umpun dzambu itoh
'That guava tree'
tree.OBL guava.OBL DEM

In the first example, 'tree' is in the absolute form (umpau). It is in the oblique form (umpun) when followed by another element within the same phrase, as in examples (2) and (3). 'Guava' in example (2) is in the absolute form (dzambeu), as it occurs in final position. It is in the oblique form (dzambu) when followed by another element, as in example (3). The above examples would lead us to conclude that the absolute form is used in phrase final position, whereas the oblique form is used in non-phrase final position. However, there are some exceptions. The oblique form is used when the context is already known. In the case of example (4), it is already known which guava tree is being referred to:
(4) mandzat umpun dzambu climb.oBL tree.oBL guava.oBL
'Climbing the guava tree'

3 Studies examining phrasal alternation in Kerinci include Steinhauer and Usman (1978); Prentice and Usman (1978); Usman (1988); Steinhauer (2002) (all about the Sungai Penuh variety); McKinnon (2011) and Mckinnon, Cole, and Hermon (2011) (both about the variety of Tanjung Pauh). However, so far there have been no exhaustive studies with a sociolinguistic focus. 
Phrasal alternation is still actively used by the PT speakers. However, I argue in this paper that the phrasal alternation does not have the same distribution it once had. Previous research reveals gradual language change, in which phrasal alternation starts to disappear among the younger generation (Ernanda 2011: 55).

This study describes the use of phrasal alternation by two generations in PT. It has the broader aim to investigate the nature of and reasons for language change. I begin with a survey of the language contact situation and a brief description of phrasal alternation. These two sections are followed by a description of the informants, the materials, the techniques of data collection and data analysis. The next section discusses the results, followed by a conclusion about the language use of PT speakers from different age groups.

\section{LANGUAGE CONTACT SITUATION IN PONDOK TINGGI}

A language of considerably influence to PT is the neighbouring Minangkabau language (henceforth MK). A large-scale migration from Minangkabau to Kerinci took place when the road from Sumatra's West Coast was finished in the 1920s (Watson 1984: ii). Most MK people have settled in the town of Sungai Penuh. The MK language, which is a related Malayic variety, has introduced a new dimension to the already complex language situation. The MK language has a higher social prestige than the local dialects of Kerinci. MK has become the language of trade in the city centre, as most traders are MK people.

Over decades of interaction with MK people, most native speakers of PT can now speak MK with native-like proficiency. This has led to a decreased use of the local dialect in PT, especially among younger people. Thus, PT has become a basilect, whereas MK is now the lingua franca. This is especially so among young people in the city centre, the markets, schools and other places. MK is also used when younger speakers of PT communicate with people from other villages in Kerinci. Although native PT speakers are able to communicate fluently in MK, it is rare to find MK people who can speak any Kerinci dialect. MK people are very proud of their language and use their language at every occasion.

Another language in contact with PT is the acrolectal standard Malay (Indonesian), which gradually became standardised in the previous decades. In fact, Malay has been used in PT for several centuries. Indonesian has achieved a prestigious status, especially after the proclamation of The Oath of the Youth (Sumpah Pemuda) in 1928 during the second Indonesian Youth Congress in Jakarta; one of its main points was to proclaim Indonesian as the national language. On the resultant situation of multilingualism, Moeliono (1994: 378) comments:

In the language acquisition process the low variety is learned as a mother tongue or from peers. Pre-school children may have opportunities to hear the high variety, but it is primarily acquired through formal education. The low variety is learned without explanation of grammatical rules, while the high variety is learned through study of the norms. 
Today, Indonesian is used as a formal language in schools, offices and at official occasions. The main language of the media is also Indonesian. This situation makes it inevitable for PT people to learn Indonesian alongside the other Malayic varieties in contact. However, most of them cannot hide their local accent when conversing in Indonesian, which has a rising intonation on the final syllable of phrases.

Other Kerinci dialects are yet another source of language contact in PT. Although systematic research on Kerinci dialectology is lacking as yet, Kerinci varieties display remarkable linguistic diversity; each village has its own dialect. However, it needs further research to define the exact number of dialects in Kerinci. These dialects are mutually intelligible only to a certain degree. Table 1 illustrates variation in Kerinci dialects. The absolute and oblique forms (in that order) are given for the equivalents of standard Malay (SM) or Indonesian gadis 'girl', garam 'salt' and mulut 'mouth' in the Kerinci vernaculars of Sungai Penuh (Usman 1976 and field notes), Pondok Tinggi, Dusun Baru and Koto Keras (field notes), and Tanjung Pauh Mudik, Koto Tuo, and Koto Pudung (Mckinnon 2011: 7).

\begin{tabular}{|c|c|c|c|c|c|c|c|}
\hline SM & $\begin{array}{l}\text { Sungai } \\
\text { Penuh }\end{array}$ & $\begin{array}{l}\text { Pondok } \\
\text { Tinggi }\end{array}$ & $\begin{array}{l}\text { Dusun } \\
\text { Baru }\end{array}$ & $\begin{array}{l}\text { Koto } \\
\text { Keras }\end{array}$ & $\begin{array}{l}\text { Tanjung } \\
\text { Pauh } \\
\text { Mudik }\end{array}$ & $\begin{array}{l}\text { Koto } \\
\text { Tuo }\end{array}$ & $\begin{array}{l}\text { Koto } \\
\text { Pudung }\end{array}$ \\
\hline $\begin{array}{l}\text { gadis } \\
\text { 'girl' }\end{array}$ & $\begin{array}{l}\text { gadoyh } \\
\text { gadih }\end{array}$ & $\begin{array}{l}\text { gadoyh } \\
\text { gadih }\end{array}$ & $\begin{array}{l}\text { gadoyh } \\
\text { gadih }\end{array}$ & $\begin{array}{l}\text { gaduh } \\
\text { gadih }\end{array}$ & $\begin{array}{l}\text { gadneh } \\
\text { gadiyh }\end{array}$ & $\begin{array}{l}\text { gadoyh } \\
\text { gadih }\end{array}$ & $\begin{array}{l}\text { gadoh }^{h} t \\
\text { gadih }^{h} k\end{array}$ \\
\hline $\begin{array}{l}\text { garam } \\
\text { 'salt' }\end{array}$ & $\begin{array}{l}\text { gaheng } \\
\text { gahon }\end{array}$ & $\begin{array}{l}\text { gahua } \\
\text { gahon }\end{array}$ & $\begin{array}{l}\text { gahin } \\
\text { gaheyn }\end{array}$ & $\begin{array}{l}\text { gahoa } \\
\text { gaher }\end{array}$ & $\begin{array}{l}\text { gahi } \\
\text { gahıy }\end{array}$ & $\begin{array}{l}\text { gahuyo } \\
\text { gahek }\end{array}$ & $\begin{array}{l}\text { gahuy } \\
\text { gahek }\end{array}$ \\
\hline $\begin{array}{l}\text { mulut } \\
\text { 'mouth' }\end{array}$ & $\begin{array}{l}\text { mulaw? } \\
\text { mulow? }\end{array}$ & $\begin{array}{l}\text { mulaw? } \\
\text { mulut }\end{array}$ & $\begin{array}{l}\text { mula? } \\
\text { mulu? }\end{array}$ & $\begin{array}{l}\text { mulaw? } \\
\text { mulu? }\end{array}$ & $\begin{array}{l}\text { mulak } \\
\text { mulik }\end{array}$ & $\begin{array}{l}\text { mulamp } \\
\text { mulump }\end{array}$ & $\begin{array}{l}\text { mulank } \\
\text { muluyk }\end{array}$ \\
\hline
\end{tabular}

Table 1. Dialect variation in the reflection of root-final *-V(C).

This degree of variation becomes more fascinating if one realizes that Sungai Penuh is separated from Pondok Tinggi by nothing more than a market place (where Minangkabau is the language of communication) and from Dusun Baru by a ten meter long bridge. Tanjung Pauh Mudik is only seven kilometres southeast of Sungai Penuh, Koto Keras some two kilometres west, Koto Pudung some four kilometres east, and Koto Tuo some twelve kilometres southeast. Figure 1 illustrates the language contact situation in PT. 


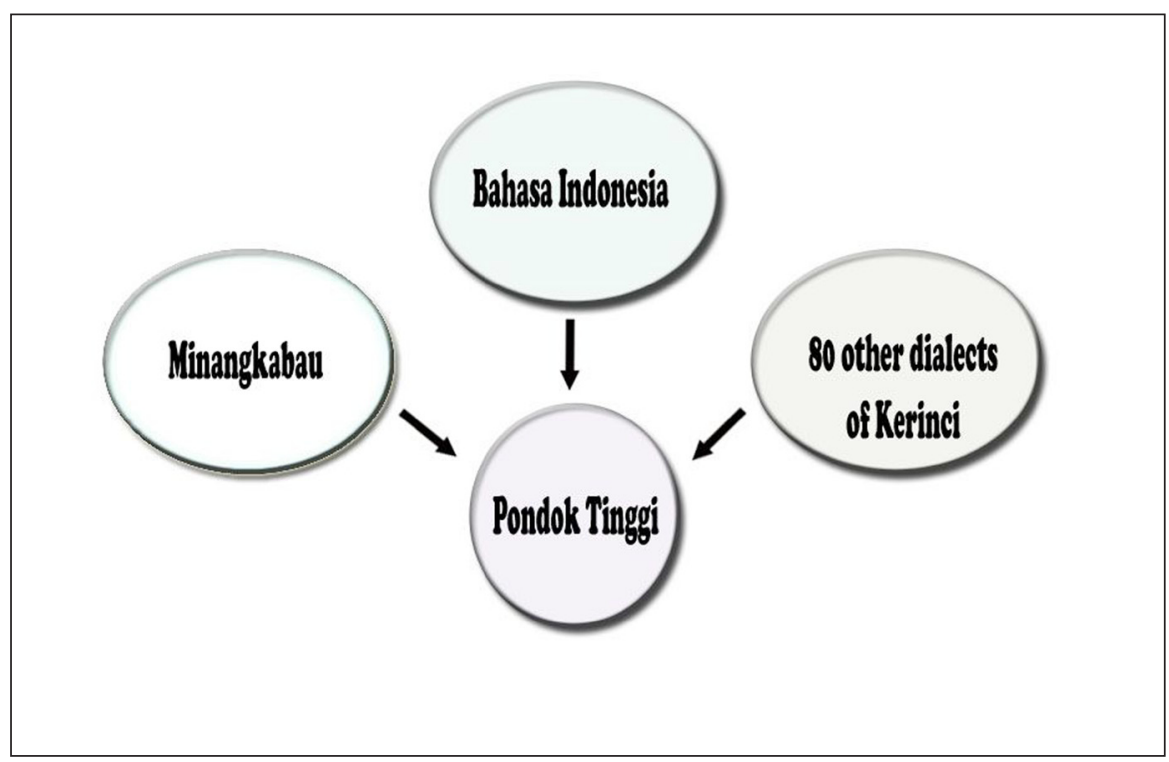

Figure 1. Language contact situation in PT.

Kerinci speakers display linguistic accommodation, in which they reduce interdialectical dissimilarities and adjust their speech to other Kerinci dialects. Trudgill (1986: 1) argues that language accommodation takes place in situations of contact among mutually intelligible but distinct dialects of the same language. He adds:

Accommodation may be incomplete in three different ways. Speakers may reduce pronunciation dissimilarities with other speakers (a) by alternating their own variant of a form with that of the other speakers, (b) by using the other speaker's variant in some words but not others, and (c) by using pronunciations intermediate between those of the two accents in contact. Of course, all three may occur in conjunction with each other (Trudgill 1986: 62).

In the case of Kerinci, when people from different villages have to communicate with each other, they do not use their own dialect but instead use an interdialect. The term "interdialect" refers to a new dialect created in interdialectal contact situations (Trudgill 1986: 62). Trudgill further highlights the significance of interdialects in the formation of new dialects. I would argue that the conditions for the formation of a new dialect are indeed present in Kerinci, although it will require a long time for it to become stable.

As I will show in what follows, the heavy language contact situation in PT affects the speech of the younger generation. At school they use Indonesian as the medium of instruction. Among peers, Minangkabau is preferred. The PT dialect is mostly used at home with parents and other family members, although some parents have stopped speaking PT to their children. As mentioned previously, the status of PT is low compared to Indonesian and Minangkabau. It can be seen in Table 2. 


\begin{tabular}{|l|l|l|}
\hline Group & Status & Overall vitality \\
\hline Bahasa Indonesia & High & High \\
\hline Minangkabau & Medium & High \\
\hline Pondok Tinggi & Low & Low \\
\hline
\end{tabular}

Table 2. The status of the languages.

The discussion above reveals that the PT dialect, with its atypical grammatical characteristics including phrasal alternation, has the lowest vitality compared to other languages in contact. The next section focuses on the implications of this situation for the use of phrasal alternation.

\section{THE PHRAsAl ALTERNATION IN PONDOK TINGGI}

As mentioned in the introduction, the majority of lexical items in PT exhibit two forms, an absolute one and an oblique. This section provides a brief outline of the original system in various grammatical categories, namely adjective phrases, noun phrases, numeral phrases, and verb phrases. The sections afterwards compare the use of phrasal alternation among older and younger speakers. The general rule of phrasal alternation is that the absolute form is used in phrase final position and the oblique form in non-phrase final position. There are some important exceptions, which are also discussed here.

\subsection{ADJECTIVE PHRASES}

PT has a limited set of adjectives. Table 3 lists some adjective phrases of degree in PT, either in isolation or in combination with a Noun Phrase (henceforth NP).

\begin{tabular}{|l|l|}
\hline \multicolumn{2}{|l|}{ 'More than' } \\
\hline a & labih 'more' + ADJ \\
\hline b & labih 'more' + ADJ daripado 'than' + NP \\
\hline 'Equal to' \\
\hline a & samo 'same' + ADJ \\
\hline b & sa- + ADJ + NP \\
\hline c & samo 'same' + ADJ + dipan 'with' + NP \\
\hline d & samo 'same' + ADJ \\
\hline 'Less than' \\
\hline a & kura 'less' + ADJ \\
\hline b & kura 'less' + ADJ + daripado 'than' + NP \\
\hline
\end{tabular}

Table 3. Adjective phrases of degree in PT. 


\subsubsection{MORE THAN THE STANDARD OF COMPARISON}

The construction labih $+\mathrm{ADJ}$ is used to describe an entity which has a higher quality than other (unmentioned) entities (5), whereas labih + ADJ + daripado $+\mathrm{NP}$ is used when the object of comparison is mentioned (6). The absolute form is used in both constructions.

(5) kuсе? no labih gәреи?

cat.OBL 3sG more fat.ABS

'His/her cat is fatter.'

(6) kuce? no labih gəpeu? daripado kuce? kamai

cat.oBL 3sg more fat.ABS than cat.oBL 1PL

'His/her cat is fatter than our cat.'

\subsubsection{EQUAL TO THE STANDARD OF COMPARISON}

The constructions samo + ADJ (7), sa- + ADJ + NP (8), and samo + ADJ + dinan + NP (9) express that the degree of quality of an entity described by the adjective equals the standard. The oblique form is used in this construction.

(7) kисе? по sато gәри?

cat.obl 3sg same fat.obL

'His/her cats are equally fat.'

(8) kuсе? nо sa-gəри? kuсе? kamai

cat.obL 3sG same-fat.oBL cat.oBL 1PL

'His/her cat is as fat as our cat.'

(9) kuсе? по samo gәри? diman kuсе? kamai cat.oBL 3sG same fat.oBL with cat.oBL 1PL

'His/her cat as fat as our cat.'

In the construction samo $+\mathrm{ADJ}(10)$, the adjective is nominalised. It expresses an equal measure compared to ADJ.

(10) kисе? nо sато gәри?
cat.obl 3 sg same fat.obl
'His/her cats are equally fat.'

\subsubsection{LESS THAN THE STANDARD OF COMPARISON}

This construction is used to describe the quality of an entity which is less than 
the standard of comparison. This construction can be formed by using kura + ADJ.oBL (11) and kura + ADJ.oBL + daripado (12).

(11)

$\begin{array}{llll}\text { kuсе? } & \text { no } & \text { kura } & \text { gәри? } \\ \text { cat.OBL } & \text { 3sG } & \text { less } & \text { fat.OBL }\end{array}$

'His/ her cat is less fat.'

(12) kuсе? no kura gәри? daripado kuce? kamai cat.OBL 3sG less fat.OBL than cat. OBL 1PL

'His/her cat is less fat than our cat.'

\subsubsection{THE SUPERLATIVE DEGREE}

This construction describes the entity with the highest degree of a certain quality. Two constructions occur; palin + ADJ (13) and the prefix ta- + ADJ (14). Both mean 'the most' and are followed by the absolute form. My data suggests that palin is used more frequently than the prefix ta-.

(13) kuсе? no palin gәреи?

cat.OBL 3sG most fat.ABS

'His/her cat is the fattest.'

(14) kисе? nо ta-gареи?

cat.OBL 3SG most.fat.ABS

'His/her cat is the fattest.'

\subsection{NOUN PHRASES}

The canonical structure of the noun phrase in PT is as follows:

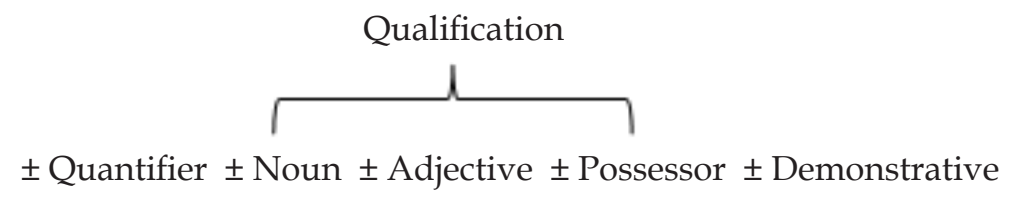

A specifying noun can follow a head noun (see Table 4). As elsewhere, the oblique form is used in non-final position. In final position, either the absolute or the oblique form can be used, depending on whether or not the context is known. 


\begin{tabular}{|c|c|c|c|}
\hline \multicolumn{3}{|c|}{ Item and origin/location } & English translation \\
\hline gunea.ABs & & & 'mountain' \\
\hline gunun.OBL & kincai.ABS & & ‘Kerinci mountain' \\
\hline gunun.OBL & kincei.OBL & itoh & 'that Kerinci mountain' \\
\hline \multicolumn{4}{|c|}{ Item and material } \\
\hline pinga.ABs & & & 'plate' \\
\hline pingan.OBL & kacao.ABs & & 'glass plate' \\
\hline pingan.OBL & kaco.OBL & itoh & 'that glass plate' \\
\hline \multicolumn{4}{|c|}{ Container and content } \\
\hline caykai.ABS & & & 'cup' \\
\hline caykei.OBL & kupai.ABS & & 'coffee cup, cup of coffee' \\
\hline caykei.OBL & kupei.OBL & itoh & 'that coffee cup' \\
\hline \multicolumn{4}{|c|}{ Classifier and item } \\
\hline bureu.ABs & & & 'bird' \\
\hline burun.OBL & ala.ABS & & 'eagle' \\
\hline burun.OBL & alan.OBL & itoh & 'that eagle' \\
\hline \multicolumn{4}{|c|}{ Status and name } \\
\hline dateu?.ABS & & & 'grandfather' \\
\hline datu?.OBL & Hasan & & 'grandfather Hasan' \\
\hline \multicolumn{4}{|c|}{ Agent and undergoer of activity } \\
\hline pandzuwua.ABs & & & 'seller' \\
\hline pandzuwon.OBL & dagon.ABS & & 'meat seller' \\
\hline pandzuwon.OBL & dagin.OBL & itoh & 'that meat seller' \\
\hline
\end{tabular}

Table 4. The noun phrases.

\subsubsection{ReLATIVE CLAuses}

A relative clause can be added to a noun phrase. The word following the relative marker is not affected by the presence of another following item and remains in the absolute form. Example (15) displays the oblique form of 'high' (tingei); its absolute counterpart (tingai) is found in the relative clause in example (16).
(15) baton
tingei itoh
(16) baton
yo tingai
itoh
stem.OBL high.OBL DEM
stem.OBL REL high.ABS DEM
'That high stem'
'The stem which is high' 
The scope of the demonstrative affects the use of the phrasal alternation. ${ }^{4}$ In example (17) the demonstrative modifies the entire NP and its entire relative clause ('that man/those men who sold a cow/cows'), indicated in the example by square brackets, and triggers the absolute form of the noun 'cow' (dzawoi). In example (18), on the other hand, the demonstrative is rather part of the relative clause where it modifies the object ' $\mathrm{Cow}^{\prime}$ ', which is therefore displays the oblique form (dzawi):

$\begin{array}{llllll}\text { [uhan } & \text { dzanton } & \text { yo } & \text { nuwon } & \text { dzawoi] } & \text { itoh } \\ \text { people.OBL } & \text { male.OBL } & \text { REL } & \text { ACT.sell.OBL } & \text { cow.ABS } & \text { DEM }\end{array}$

'That man/those men who sold a cow/cows'

$\begin{array}{llllll}\text { uhan } & \text { dzanton } & \text { yo } & \text { nuwon } & {[\text { dzawi }} & \text { itoh }] \text {. } \\ \text { people.OBL male.OBL REL ACT.sell.oBL } & \text { cow.OBL } & \text { DEM } \\ \text { 'A man/men who sold that cow/those cows' } & & \end{array}$

\title{
3.2.2 PREPOSITIONAL PHRASES
}

Words following a preposition can occur both in the absolute and oblique form. The oblique form is used within a single noun phrase and implies that the context is known (dapu in example (19)), whereas the absolute form is used in adverbial constructions (dapeu in example (20)).

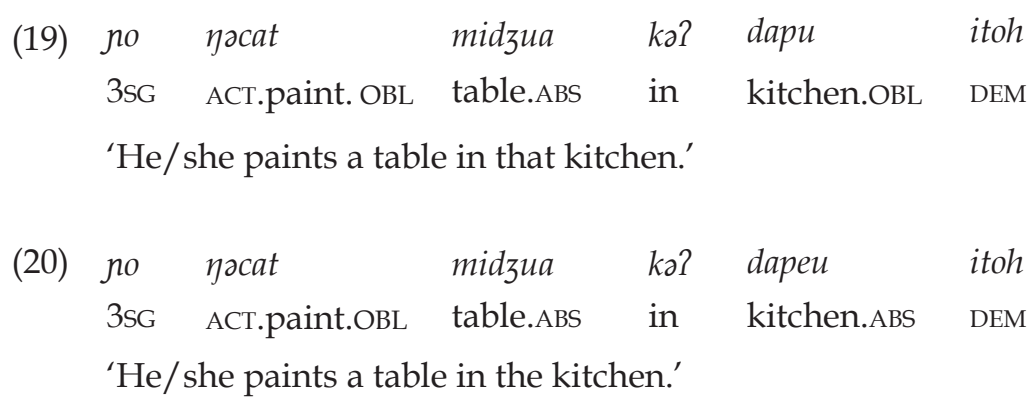

\subsection{NUMERAL PHRASES}

The last unit of a compound numeral displays the absolute form, all preceding units are oblique forms. This is exemplified in (21).

\author{
[How many chickens do you want?]
(21) duwo pulauh
two.OBL tens.ABS
'Twenty'

4 This was first pointed out by Steinhauer and Usman (1978) in their description of the Sungai Penuh dialect. 
Numeral classifiers are optional, in which case the classifier takes the absolute form and all units of the compound numeral take the oblique form, as in example (22).

[How many chickens do you want?]

$\begin{array}{lll}\text { (22) duwo puluh ikau } & \\ \text { two.OBL tens.OBL } & \text { CLF.ABS } \\ & \text { 'Twenty animals' } & \end{array}$

\subsubsection{ORDINAL NUMERALS}

Ordinal numerals are created by prefixing $k a-$ to cardinal numerals. This is exemplified in (23). As elsewhere, the oblique form indicates that the context is known, as is shown in example (24).
(23) ano?
ka-duwea
child.OBL $\quad k a$-two.ABS
'The/a second child'
(24) ano? ka-duwo
child.OBL $\quad k a$-two.oBL
'(His/her) second child'

\subsubsection{FRACTIONAL NUMERALS}

In the case of fractional numerals, the speakers of PT do not have a clear preference for either absolute or oblique form. The following variations are attested:

$$
\begin{array}{lll}
\text { (25a) } & \begin{array}{l}
\text { duwo } \\
\text { two.OBL }
\end{array} & \begin{array}{l}
\text { por-tigea } \\
\text { par-three.ABS }
\end{array} \\
\text { (25b) } & \begin{array}{l}
\text { duwea } \\
\text { two.ABS }
\end{array} & \begin{array}{l}
\text { prr-tigo } \\
\text { pr-three.OBL }
\end{array} \\
\text { (25c) } & \begin{array}{l}
\text { duwo } \\
\text { two.OBL }
\end{array} & \text { por-tigo } \\
& \text { 'Two-three.OBL }
\end{array}
$$

\subsubsection{COLLECTIVE NUMERALS}

The prefixes $k a$ - and $b a$-are used to form different types of collective numerals. The collective numerals with the prefix ka- precede the counted item and occur in the oblique form. 

$\begin{array}{lll}\text { (26) } & \text { umo-duwo } & \text { itoh } \\ \text { ka-two.oBL } & \text { house.OBL } & \text { DEM }\end{array}$
'Both of those houses'

The collective numerals with the prefix $b a$-follow the counted item and occur in the absolute form.
(27)

$\begin{array}{lll}\text { kamai ba-duwea napou } & \text { lantae } \\ \text { 1PL ba-two.ABS } & \text { AcT.sweep.OBL } & \text { floor.ABS } \\ \text { 'We both swept the floor.' } & \end{array}$

\subsection{VERB PHRASES}

PT has transitive and intransitive verbs. The transitive verbs can form active, passive and imperative sentences, whereas the intransitive verbs cannot. The paradigm of the transitive verbs can be seen in Table 5 .

\begin{tabular}{|l|l|l|}
\hline & Absolute & Oblique \\
\hline Active & N+ root.ABS & N+ root.OBL \\
\hline $\begin{array}{l}\text { Passive (3rd person pronoun/ } \\
\text { agent) }\end{array}$ & di- + root.ABS & di- + root.OBL \\
\hline $\begin{array}{l}\text { Passive (1st, 2nd person pronoun/ } \\
\text { agent) }\end{array}$ & personal marker + root.ABS & \\
\hline Imperative & root.ABS & \\
\hline
\end{tabular}

Table 5. The paradigm of the transitive verbs.

\subsubsection{ACTIVE TRANSITIVE}

The absolute form is used in final position as can be seen in example (28). The oblique form is used when the verb is followed by a patient (29). The oblique form is also used when the context is already known (30).

[What is he / she doing?]

(28) no maykau

3SG ACT.hoe.ABS

'He / she is hoeing.'

(29) no nәрои? akau

3SG ACT.hit.OBL 1SG

'He/she hits me.' 
[Who hit you?]

(30) no nopou?

3SG ACT.hit.OBL

'He / she hits (me).'

\subsubsection{PASSIVE TRANSITIVE}

The passive marker $d i$-is used with the third personal pronoun. Both absolute and oblique forms can be used in this construction. The absolute form is used in (31). The use of the oblique form is exemplified in (32). It can also be used in final position when the agent is already known from the context (33).

(31) itoh di-boloi
house.OBL DEM PAss-buy.ABS
'That house was bought.'

(32) umoh itoh di-bali no

house.OBL DEM PASS-buy.OBL 3SG

'That house was bought by him/her.'

$\begin{array}{lll}\text { (33) } & \text { itohoh } & \text { di-bali } \\ \text { house.OBL } & \text { DEM } & \text { PASs-buy.OBL }\end{array}$

'That house was bought.'

The first and second person pronouns can only form passive constructions with a verb root in the absolute form.

(34) itoh akau boloi
house.OBL DEM 1sG buy.ABS
'That house was bought by me.'

\subsubsection{IMPERATIVE SENTENCES}

The verb root in the absolute form is used to form an imperative sentence (35). The prefix di- can be added to add a dimension of politeness (36).
(35) bacea suhat ineh
read.ABS letter.OBL DEM
'Read this letter!' 


$\begin{array}{lll}\text { (36) di-bacea } & \text { suhat } & \text { ineh } \\ & \text { PAss-read.ABS letter.OBL } & \text { DEM } \\ \text { 'Please read this letter!' } & \end{array}$

\subsubsection{INTRANSITIVE VERBS}

Intransitive verbs cannot be combined with active or passive prefixes. It occurs in the absolute form in imperative constructions (37a) and in final position (37b). It is in the oblique form when followed by an adverb (38a). In the latter case, the oblique form can often be interpreted as a nominalised verb (38b).
(37a) dudeu? tona
sit.ABS calm.ABS
'Sit calmly!'
(38a) dudu? tana
sit.OBL calm.ABS
'Sitting calmly'

\author{
(37b) dudeu? no \\ sit.ABS 3SG \\ 'He/she sits.'
}

(38b) dudu? no tona
sit.OBL 3sG calm.ABS
'His/her seat is comfortable.'

This concludes the skeleton description of phrasal alternation in PT. ${ }^{5}$ The next section presents a sociolinguistic experiment on the degree of the change in the use of the phrasal alternation among the younger generation.

\section{AN EXPERIMENT ON THE LANGUAGE CHANGE IN PONDOK TINGGI}

The conservative grammatical patterns described in section 3 are no longer maintained by the younger speakers of PT. Therefore, I have designed an experiment to elicit the use of the absolute and the oblique form in order to examine the present-day distribution of phrasal alternation across two generations. A brief overview of my method is presented in this section.

\subsection{PARTICIPANTS}

This article draws primarily from the data I collected in the summer of 2013 with twelve native speakers of the PT dialect. A group of six older speakers and one of six younger speakers of PT participated in this research. Each age group consisted of three female and three male speakers. The age of the older speakers ranged from 52 to 74 years and that of the younger speakers from 17-27 years. All speakers were born and still live in PT. They predominantly leave home for holidays. All speak PT as their mother tongue, except two siblings who speak both PT and localized Indonesian (Malayu tinggai) at home. The older speakers are mostly low educated. Their highest level of education

\footnotetext{
5 A detailed description of the complex system of phrasal alternation will be presented in my forthcoming $\mathrm{PhD}$ thesis.
} 
is elementary school. They all work as farmers. The average education of the younger speakers is high school. At present they are mostly students. All speakers are multilingual, as discussed in the introduction. I collected information about the sociolinguistic background of the participants by using a sociolinguistic questionnaire, consisting of detailed information about the participants, their family history and their language use.

The speakers who participated in this research live mostly in the hilly suburban area of Pondok Tinggi called Sungai Jernih. A small group live in villages near Sungai Penuh, the city centre. Their exact location does not impact too much on the speech of the older group, but has a big influence on that of the younger group. I argue that the closer they live to the city centre, the more their PT fluency has been influenced by MK, since MK is broadly used in the city centre. The results would presumably have been different if the interview involved younger speakers who live closer to the city centre.

\subsection{THE MATERIAL}

The material used in this study is a questionnaire consisting of 432 phrases and sentences in Indonesian. The speakers were asked to translate all phrases/ sentences from Indonesian into PT. The use of phrasal alternation is tested in different contexts and word categories (adjectives, nouns, numerals, and verbs).

This material was taken from my earlier research on the use of the phrasal alternation in the PT dialect. The following sentences, for example, were used in the category of nominal phrasal alternation:

\begin{tabular}{|c|c|c|c|c|}
\hline $\begin{array}{l}\text { Indonesian sample } \\
\text { sentences }\end{array}$ & \multicolumn{4}{|c|}{ PT translations from participants } \\
\hline $\begin{array}{l}\text { Orang menyambut } \\
\text { bulan puasa. }\end{array}$ & $\begin{array}{l}\text { uha } \\
\text { people.ABS } \\
\text { 'People are }\end{array}$ & $\begin{array}{l}\text { nambut } \\
\text { ACT.welcome.OB } \\
\text { welcoming the fa }\end{array}$ & $\begin{array}{l}\frac{\text { bulon }}{\text { month }} \\
\text { ng mor }\end{array}$ & $\frac{\text { puasao }}{\text { fasting.ABS }}$ \\
\hline $\begin{array}{l}\text { Bulan puasa ini aku } \\
\text { pulang. }\end{array}$ & $\begin{array}{l}\text { bulon } \\
\text { month.OBL } \\
\text { 'This fastin }\end{array}$ & $\begin{array}{l}\text { puaso ineh } \\
\text { fasting.OBL DEM } \\
\text { month I go back }\end{array}$ & $\begin{array}{l}\text { akau } \\
\text { 1sG } \\
\text { lome).' }\end{array}$ & $\begin{array}{l}\text { baloi? } \\
\text { back.ABS }\end{array}$ \\
\hline
\end{tabular}

Table 6. The examples of the questionnaire.

\subsection{TECHNIQUES OF DATA COLLECTION}

The interviews with the speakers were conducted in PT. However, I sometimes had to switch to Indonesian, Jambi Malay or Minangkabau while interviewing some younger speakers. Although they were more comfortable speaking these other languages, most of the time I tried to speak PT with them. With the older speakers, PT was used without code-switching or code-mixing.

In the interview process, older speakers gave much information about the contexts, the meaning of words, and some specific examples. The 
interviews took two to five hours per participant and were all filmed and recorded. Interestingly, I found some younger speakers who were unwilling to participate in interviews. They thought their PT ability was not good enough and were afraid to make mistakes in the interviews. After assuring them that there would not be any negative consequences, they were still hesitant to participate because of their perceived lack of fluency in PT. As a PT speaker myself, I suspect that my presence during the experiment caused unease among these participants to have their language skills subjected to systematic research.

\subsection{TECHNIQUES OF DATA ANALYSIS}

After collecting the audio/video data, I transcribed everything myself. The transcribed data was coded based on the variations made by the speakers. Eight variations occurred:

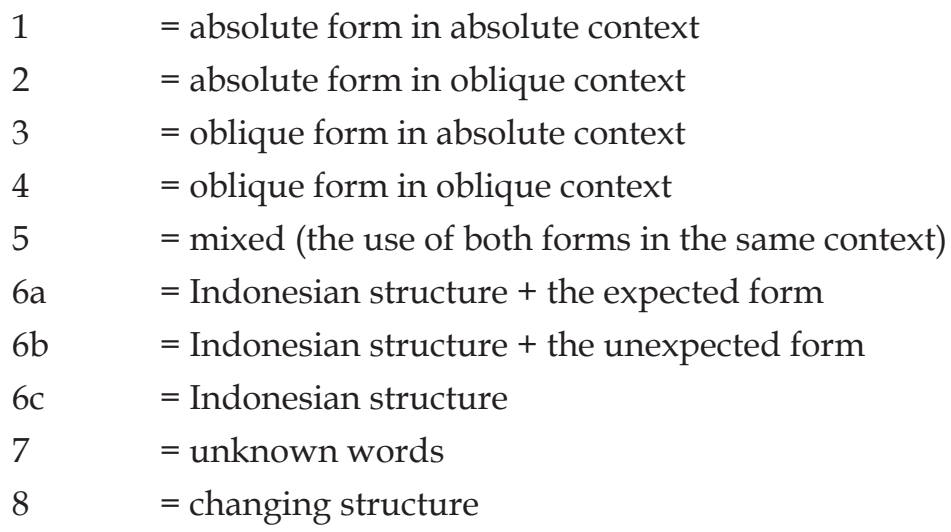

To illustrate my modus operandi, I give some examples taken from the adjective category. The first example is the use of the absolute form in the absolute context in a construction that compares degrees of quantity, using the particle lebih 'more'. When the participants gave the absolute form, I coded the particular example as 1 (Table 7).

\begin{tabular}{|l|llll|c|}
\hline Indonesian sample sentences & PT translations from participants & Coding \\
\hline Mobilnya lebih mahal. & uto & no & $\underline{\text { labih }}$ & $\underline{\text { maha }}$ & 1 \\
& car & 3sG & more & expensive.ABS & \\
& 'His/her car & more expensive.' & \\
\hline
\end{tabular}

Table 7. Coding: the use of the absolute form in the absolute context.

The use of the absolute form where one would expect the oblique is coded as 2 (Table 8). 


\begin{tabular}{|l|l|c|}
\hline Indonesian sample sentences & PT translations from participants & Coding \\
\hline Kami sama pandai. & kamai samo pandae & 2 \\
& 1PL same clever.ABS & \\
& 'We are equally clever.' & \\
\hline
\end{tabular}

Table 8. Coding: the use of the absolute form in the oblique context.

The use of the oblique form where one would expect the absolute is coded as 3 (Table 9). The following example is taken from the adjective category. With the article $s i$, the adjective should be in the absolute form.

\begin{tabular}{|l|lll|c|}
\hline Indonesian sample sentences & PT translations from participants & Coding \\
\hline$\underline{\text { Si dungu menurut saja. }}$ & $\underline{s i} \quad \underline{d u \eta u} \quad$ nuhau? woa & 3 \\
& ART stupid.OBL follow.ABS only & \\
& 'The stupid person only becomes a & \\
& follower.' & \\
\hline
\end{tabular}

Table 9. Coding: the use of the oblique form in the absolute context.

The example below illustrates the use of the oblique form in the oblique context. The example sentence features a comparison of degree formed by samo + ADJ. When the participants gave the oblique form, I coded the particular example as 4 (Table 10).

\begin{tabular}{|l|l|c|}
\hline Indonesian sample sentences & PT translations from participants & Coding \\
\hline Kami sama pandai. & kamai samo pande & 4 \\
& 1PL same clever.oBL & \\
& 'We are equally clever.' & \\
\hline
\end{tabular}

Table 10. Coding: the use of the oblique form in the oblique context.

I use code 5 for mixed forms. It refers to fluctuation between absolute and oblique forms in the same context. I have included various sentences with the same construction to test this (Table 11).

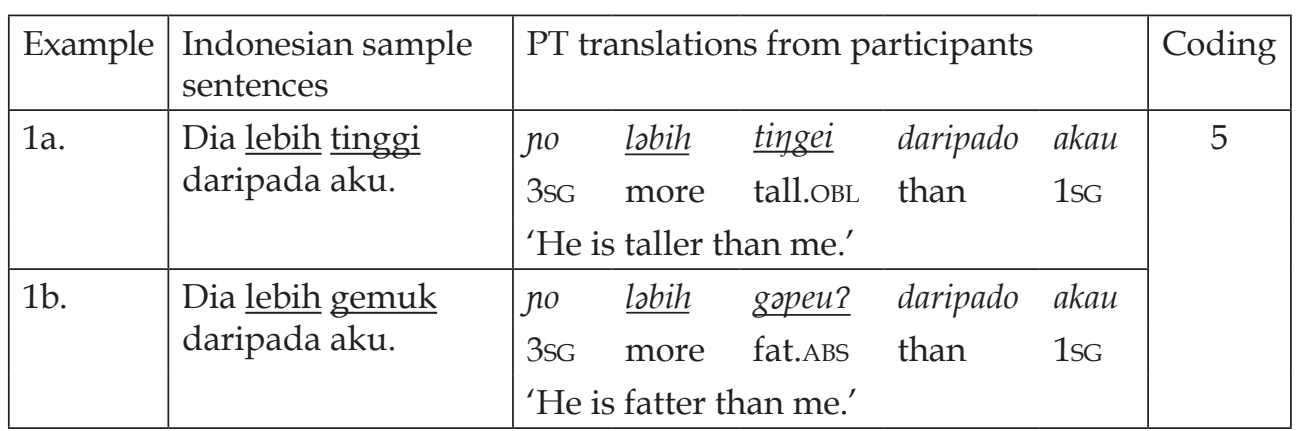

Table 11. Coding: the use of the mix forms (both forms in the same context). 
Some speakers exhibit grammatical influence from Indonesian. I divided this variant into three types. The first type, $6 a$, is the use of a structure from Indonesian with the expected type of phrasal alternation. The second type, $6 \mathrm{~b}$, is the use of a structure from Indonesian with an unexpected type of phrasal alternation. The last type, $6 \mathrm{c}$, is the borrowing of entire constructions from Indonesian without adjustment to PT.

The examples in adjective category are presented in Table 12. The first example is a superlative construction. Instead of using the PT construction $t a-+A D J$, the prefix tar-is taken from Indonesian. The next example shows a combination of borrowing an Indonesian prefix per- (expected pa-) and using the wrong type of phrasal alternation. In the third example, phrasal alternation is avoided altogether by borrowing a word from Indonesian.

\begin{tabular}{|c|c|c|}
\hline Indonesian sample sentences & PT translations from participants & Coding \\
\hline Kudanya tercepat. & $\begin{array}{l}\text { kudo no } \frac{\text { tər-koah }}{\text { horse.oBL }} \text { 3sG tər(Ind.)-fast.ABS } \\
\text { 'His/her horse was the fastest.' }\end{array}$ & $6 a$ \\
\hline Diperbesar jalan itu. & $\begin{array}{lll}\text { di-par-gadon } & \text { dzalon } & \text { itoh } \\
\text { PASS-par(Ind.)-big.OBL } & \text { road.OBL } & \text { DEM } \\
\text { ‘Broaden that road!' } & & \\
\end{array}$ & $6 b$ \\
\hline Aku tahu seberapa manis. & $\begin{array}{l}\text { akeu taau barapo } \quad \text { manis } \\
\text { 1sG know.ABs how much.oBL sweet(Ind.) } \\
\text { 'I know the amount of sweetness/I } \\
\text { know how sweet it is.' }\end{array}$ & $6 c$ \\
\hline
\end{tabular}

Table 12. Coding: the use of the structure of Indonesian.

The use of words unknown to PT and only found in the data of younger speakers is coded as 7 . These are analogous forms created on the base of perceived sound correspondences between PT and Indonesian. In the example in Table 13, the consultant created the form gunau 'mountain' based on Indonesian gunung. However, the default form in PT is gunea.

\begin{tabular}{|l|lc|c|}
\hline Indonesian sample sentences & PT translations from participants & Coding \\
\hline Pendaki gunung & pandakei gunau & 7 \\
& $\begin{array}{l}\text { pan-climb.oBL } \quad \text { mountain } \\
\text { 'A mountain climber' }\end{array}$ & \\
\hline
\end{tabular}

Table 13. Coding: the use of the unknown words.

Changes in the structure of the sentences are coded as 8 . In the example below, the expected translation consists of only one word, baumuah 'to have a house'. However, the participant in Table 14 restructures the sentence structure altogether. 


\begin{tabular}{|c|c|c|}
\hline $\begin{array}{l}\text { Indonesian } \\
\text { sample sentences }\end{array}$ & PT translations from participants & Coding \\
\hline $\begin{array}{l}\text { Jangan berumah } \\
\text { di tepi pantai. }\end{array}$ & $\begin{array}{l}\text { mo? nəgua? } \underline{\text { umah }} \text { kə? topei pantae } \\
\text { NEG ACT.build.ABS house.ABS PREP side.OBL beach.ABS } \\
\text { 'Don't have / build a house near the beach.' }\end{array}$ & 8 \\
\hline
\end{tabular}

Table 14. Coding: changing structure.

\section{THE RESULTS AND DISCUSSION}

This section presents the results of a statistical calculation based on the codes introduced in the previous section. This allows a renewed analysis on the use of phrasal alternation, influence from Indonesian, the creation of new forms, and the change of sentence structures in PT.

\subsection{THE USE OF PHRASAL ALTERNATION}

Both generations mix up the absolute and oblique forms, yet the tendency is much stronger among the younger generation. Table 15 depicts the percentages per generation of wrong use of phrasal alternation (codes 2 and 3 ).

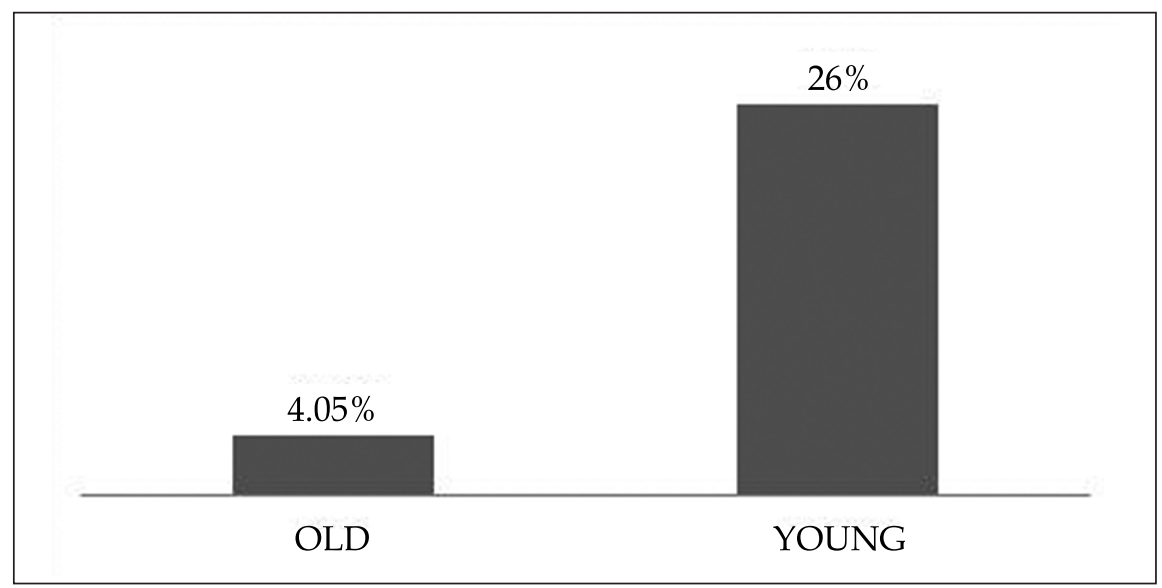

Table 15. Wrong use of phrasal alternation.

In order to find out if the means of the variant rates were different between the old and the young group, I performed an independent samples t-test with a significance threshold of $p=0.05$. Based on the results of this test, I conclude that the means are significantly different $(t(10)$...). The younger group use more absolute forms in oblique contexts and oblique forms in absolute contexts than the older group $(t(10)=-17,95, p<.001)$. This is a clear indicator of language shift. It occurs not only among the younger group, but also among the older group, albeit in a lower percentage.

In general, the speakers also display fluctuation between the absolute and oblique forms in the same context (code 5). This occurs mostly among the 
older group. As it turns out, they did not have any preference and randomly chose one form when confronted with example sentences. This shows that the absolute-oblique distinction is increasingly less fixed or stable. However, this occurs only in certain constructions. A more detailed discussion of these variants is provided in the sub-sections below.

\subsubsection{PER CATEGORY}

Table 16 shows which word categories are most sensitive to erroneous phrasal alternation. In the older group, the highest number of these variants occurs in verbs $(5.61 \%)$, followed by numerals $(4.28 \%)$, nouns $(4.13 \%)$ and adjectives $(1.51 \%)$. The younger speakers display the highest percentage variation in adjectives (29.22\%), followed by nouns (27.63\%), numerals (26.42\%) and verbs $(20.91 \%)$.

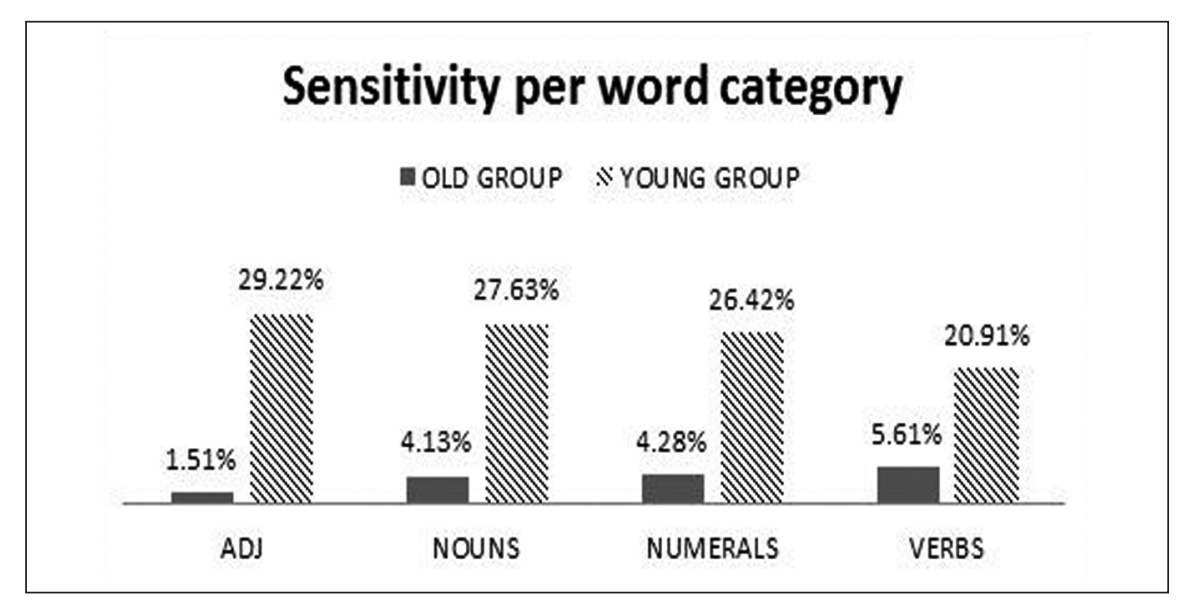

Table 16. Sensitivity per word category.

\subsubsection{PER VARIANT}

In investigating the directionality of change (Table 17), the most striking percentage is the use of the absolute form in the oblique context, occurring in both generations. The absolute form is used in oblique contexts in $20.75 \%$ of the examples by the younger generation and in $1.81 \%$ of the older generation. Both generations also use the oblique form in absolute contexts, albeit in insignificant percentages.

There thus seems to be a tendency to use the absolute form in oblique contexts, especially among younger speakers. 


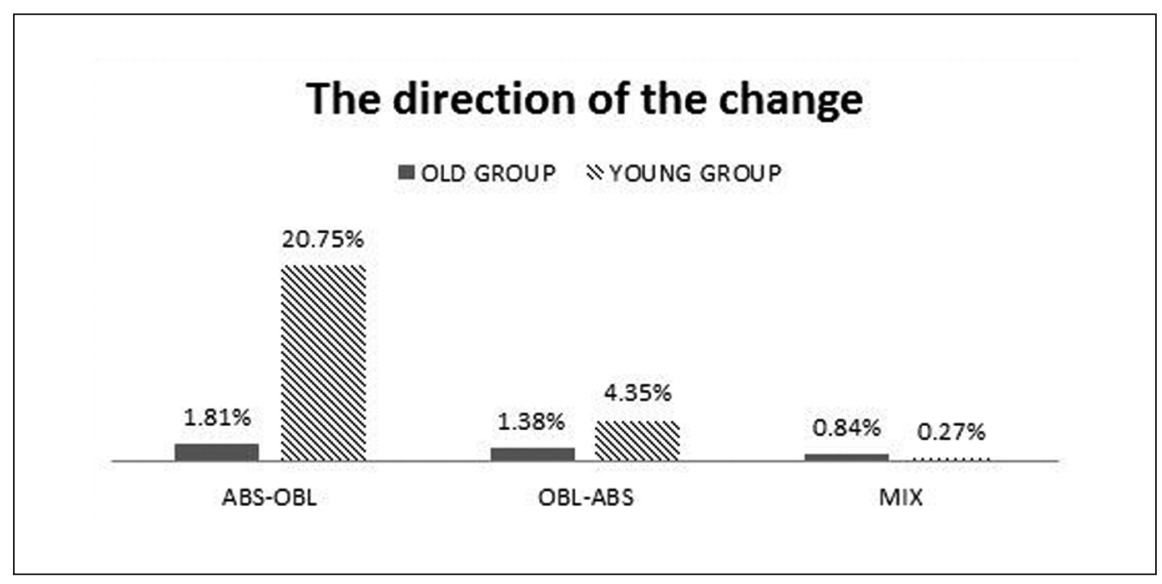

Table 17. The direction of the change.

\subsection{THE USE OF INDONESIAN}

The use of Indonesian is only found among the younger group (Table 18). None of the older speakers needed to resort to Indonesian during my research.

\begin{tabular}{|l|l|l|}
\hline Variant 6a & Variant 6b & Variant 6c \\
\hline $4.35 \%$ & $1.50 \%$ & $5.94 \%$ \\
\hline
\end{tabular}

Table 18. The use of Indonesian in the younger group.

In the highest number of cases, younger speakers use of Indonesian without adjustment into PT (5.94\%). They simply take words from Indonesian when they do not know how to express the same idea in PT. Other words are adopted without any adjustment to PT, such as poncarian 'earnings' in example (39).

$$
\begin{array}{lll}
\text { (39) no } & \text { idzia } & \text { pancarian } \\
\text { 3sG } & \text { NEG } & \text { earnings (Ind.) }
\end{array}
$$

'He/she does not have earnings.'

In example (40), a young speaker adds the Indonesian nominalizing suffix -an to a PT word. PT itself is a non-suffixing language.

$$
\begin{aligned}
& \text { (40) no məna umah-umah-an } \\
& \text { 3sG make.ABS RED-house.ABS-NMLZ(Ind.) } \\
& \text { 'He/she makes houses.' }
\end{aligned}
$$

In example (41), the Indonesian prefix pam- (expected pam-) is applied to a PT verb. The consultant also uses the absolute form where the oblique form would have been required. 
(41)
pam-bacea
barita
NMLZ(Ind.)-read.ABS news(Ind.)
'A news reader'

The fact that both PT and Indonesian are Malayic languages makes it easier to exchange elements between them. Thomason (2001: 71) notes that "[...] in contact situations between typologically similar languages, the fact that some structural features are easier to borrow than others has to do with relative degrees of integration into grammatical subsystems". The author stresses the importance of typological distance between two languages; closely matching structures facilitate borrowing. This is true not only lexicons, but also - perhaps especially - for grammatical units such as morphemes, particles and affixes (Thomason 2006: 2).

My data suggest that younger speakers have a lower proficiency in PT than in Indonesian, which they use a lot at school. It is easier for them to borrow elements from Indonesian and put them into a PT structure. On the other hand, older speakers are hardly influenced by Indonesian, since they only use it for infrequent official occasions.

\subsection{THE USE OF NEW FORMS}

The use of newly created forms is only attested among younger speakers and occurs in 5.2\% of the cases. Such forms are created based on known or assumed sound correspondences between Indonesian and PT, yet are not indigenous to the PT dialect. Illustratively, I have frequently encountered form sajur kaykao (the correct form: sakaykun) as a translation of Indonesian sajur kaykuy 'water spinach'. This form presumably reflects the fact that the diphthong ao is perceived to be a characteristic of PT. However, the word kaykao in PT means 'frog', making the phrase either meaningless or the result of false association. It shows the creativity of young people in creating new forms; "teenagers are famous for their linguistic creativity, especially, but not only, in lexical innovation" (Thomason 2008: 11).

\subsection{THE CHANGE OF THE CONTEXT}

Both older $(0.80 \%)$ and younger $(1.58 \%)$ speakers change the structure of their sentences in some contexts as indicated in Table 14. I would argue that they do so to make their sentences sound more natural.

\section{DISCUSSION}

My data reveal gradual language change in PT, especially with regard to phrasal alternation. The language used by the older generation is different from the one used by young people. Overall, speakers tend to use more absolute forms, even in oblique contexts. The highest frequency of this usage is found in the younger group, who show a clear preference for absolute forms.

There are two possible explanations for this change. First, it might a 
matter of frequency. The older speakers use the absolute form more often and the children therefore hear it more often than the oblique form. This would then be a case of "priming", a cognitive phenomenon in which earlier experience influences a response to current stimulus (Horner and Henson 2008: 1979). The second possible explanation could be the relatedness of PT to Indonesian. Since the absolute forms, with their diphthongs, tend to look more "non-Indonesian", it is preferred in a subconscious attempt to keep the languages separate. The observed examples would then be the result of an overgeneralization of the absolute-oblique distinction.

To have a better idea of the processes at play, I call attention to the terms "language divergence" and "language convergence" Crystal (2008: 154) defines "language divergence" as "a process of dialect change in which the dialects become less like each other". "Language convergence" is defined as "a process of dialect change in which the dialects become more like each other" (Crystal 2008: 113).

It should be noted here that both absolute and oblique forms can be more divergent from their counterparts in Indonesian, depending on the wordfinal vowel. As indicated in Table 1, phrasal alternation in Kerinci dialects is characterized by complex sound changes. Low vowels in Indonesian tend to have "divergent" oblique equivalents in PT, whereas high vowels display "divergent" absolute equivalents (42). Overall, however, the absolute forms tend to resemble their Indonesian counterparts less than the oblique forms:

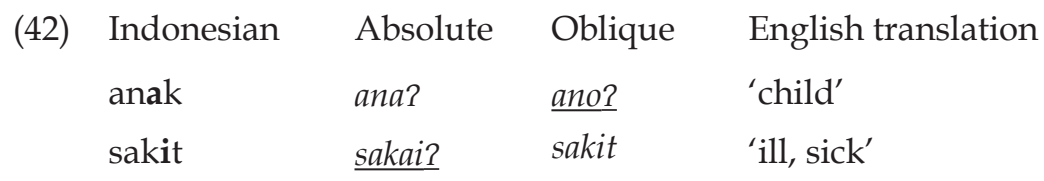

Based on these correspondences, I would argue that young PT speakers prefer the more divergent forms (in most cases the absolute forms) to stress that they are speaking PT. They try to show their PT identity by making their speech sound less like Indonesian, yet end up hyper-correcting their grammar. The future will tell whether this is indeed a temporary phenomenon rooted in the desire to highlight one's identity, or whether it reflects a long-term change. In the latter case, the next generation might gradually lose the oblique form and only maintain the absolute form. Hinskens, Auer, and Kerswill (2005: 6) comment that

[...] motivations for short-term divergence may range between strictly situational (the desire to distance oneself from one's conversational partner) or more general (the need to develop, maintain, or stress social or personal identity, or to demarcate the in-group from the relevant outgroup). In the longer term, language can thus become an identity marker of an entire minority group (as in the case of Welsh, Basque, Catalan, Frisian, and Lëtzebuergesch).

My data show that this might be the case with PT, in which young speakers 
exaggerate the differences with Indonesian.

On a grammatical level, my data reveal that speakers no longer have clear preferences regarding the use of the absolute versus the oblique form. The frequent use of Indonesian by the younger speakers has given rise to some difficulties in expressing ideas in PT. Indonesian as the medium of instruction at schools may sooner or later replace the native language. Minangkabau, the widely used trade language, should also be considered a threat to the native language, since it is the preferred language among younger speakers. The use of newly created forms shows that younger speakers encounter difficulties in expressing certain ideas in their native language. They tend to find creative solutions for this lack of proficiency.

As regards the reasons behind these changes, I argue that there are two main contributive factors: the internal factor and external factor. Thomason and Kaufman (1988: 61) clarify that both factors can trigger language change. The internal factor of change in PT is the simplification among young speakers of the complex absolute-oblique distinction, whose shapes are influenced in complex ways by other phonemes within the same word. The external factor cannot be separated from the internal factor since they are related processes in PT. The move from an absolute-oblique distinction towards the use of only one form is in all likelihood due to frequent contact with speakers of Indonesian and Minangkabau, two prestigious languages that lack this distinction. The result can be called simplification; the contact-induced erosion of the idiosyncratic process of phrasal alternation.

The PT data clearly demonstrate contact-induced simplification as described by Trudgill (2011: 15). Indonesian and Minangkabau slowly replace the native language among younger speakers. Using these prestigious languages can be seen as a strategy of self-representation as modern citizens. In the light of their reduced proficiency in PT, it may be predicted that the use of oblique forms will disappear in the next generation.

\section{CONCLUSION}

Situated at the heart of a multilingual landscape, the PT speech community cannot avoid contact with speakers of related Malayic varieties. This paper has illustrated how more prestigious languages, such as Indonesian and Minangkabau, assert lexical and grammatical influence on the PT basilect. This leads to a decreased proficiency in the native language as well as a process of gradual, contact-induced language change.

This study highlighted the use of the language, in particular of the grammatical phenomenon of phrasal alternation, of two generations of native PT speakers. The results show various ways in which the speech of the older generation differs from that of the younger speakers. There is a tendency, especially among younger speakers, to use the absolute form in all contexts. Among older speakers, this tendency occurs most strongly in verb phrases, whereas among younger speakers it is the strongest in adjective phrases.

The younger speakers simplify their language by using only one form of 
the originally two-fold absolute-oblique distinction. In doing so, they prefer the absolute form, which looks more "un-Indonesian". I argue that this is the result of a tendency to distinguish PT from Indonesian, at least in the context of a bilingual questionnaire and perhaps elicitation through Indonesian in general. They also create new forms in (perceived) analogy with Indonesian, suggesting that younger speakers are gradually losing the ability to express themselves fully in PT.

Internal and external factors have been considered as the engine behind language change in PT. Simplification of the phonologically complex process of phrasal alternation appears to be an internal factor, whereas several contactinduced phenomena should be classified as external factors. Language change is difficult to avoid in a community as multilingual as this one. In view of the patterns of language change observed here, I predict that the process of phrasal alternation will gradually disappear. Due to the imperfect control of PT among young speakers at present and their preference for absolute forms, is seems unlikely that the oblique form will be passed on to the next generation of speakers.

The spread and near-universal acceptance of Indonesian is typically presented as a success story for the Indonesian people. While originally lacking native speakers, this language is indeed spoken by $80 \%-90 \%$ of the Indonesian population. This research calls attention to a darker story behind the shining light of the national language, as behind its success lies an enormous pressure on the local languages. In many cases, including that of PT, this pressure has resulted into language loss.

This study is by no means the last contribution to this topic. Further research is hoped to foreground other sociolinguistic factors, such as the geographical area, education, and occupation of the consultants. The extent to which such background factors are of influence to language change is yet to be determined. Another possible topic for further research would be to examine the ability of PT speakers in other languages, such as Indonesian and Minangkabau, to determine in which languages they can best express themselves and whether this differs from one domain to another.

$\begin{array}{cl}\text { ABBREVIATIONS USED } \\ 1 & : \text { first person } \\ 2 & : \text { second person } \\ 3 & : \text { third person } \\ \text { ABS } & : \text { absolute } \\ \text { ACT } & : \text { active } \\ \text { ADJ } & : \text { adjective } \\ \text { ART } & : \text { article } \\ \text { CLF } & : \text { classifier } \\ \text { DEM } & : \text { demonstrative }\end{array}$




$\begin{array}{ll}\text { Ind } & \text { : Indonesian } \\ \text { MK } & : \text { Minangkabau } \\ \text { NEG } & : \text { negation } \\ \text { NMLZ } & : \text { nominalizer } \\ \text { NP } & : \text { noun phrase } \\ \text { OBL } & \text { : oblique } \\ \text { PASS } & \text { : passive } \\ \text { PL } & : \text { plural } \\ \text { PREP } & : \text { preposition } \\ \text { PT } & : \text { Pondok Tinggi } \\ \text { RED } & : \text { reduplication } \\ \text { REL } & : \text { relative } \\ \text { SG } & : \text { singular } \\ \text { SM } & : \text { Standard Malay }\end{array}$

\section{REFERENCES}

Crystal, David. 2008. A dictionary of linguistics and phonetics. Sixth edition. Oxford: Blackwell.

Ernanda. 2011. "On the loss of the phrasal alternation in Pondok Tinggi dialect of Kerinci; A stochastic optimality theory approach". MA thesis, Radboud University Nijmegen.

Hinskens, Frans, Peter Auer, and Paul Kerswill. 2005. "The study of dialect convergence and divergence; Conceptual and methodological considerations", in: Peter Auer, Frans Hinskens, and Paul Kerswill (eds), Dialect change; Convergence and divergence in European languages, pp. 1-48. Cambridge: Cambridge University Press.

Horner, A.J and R.N. Henson. 2008. "Priming, response learning and repetition suppression", Neuropsychologia 46: 1979-1991.

Mckinnon, Timothy. A. 2011. The morphophonology and morphosyntax of Kerinci word-shape alternations. PhD thesis, Delaware University.

Mckinnon, Timothy. A, Peter Cole, and Gabriella Hermon. 2011. "Object agreement and 'pro-drop' in Kerinci Malay", Language 87/4 (December): 715-750.

Moeliono, Anton. M. 1994. “Contact-induced language change in presentday Indonesian", in: Dutton T and D.T. Tyron (eds), Language contact and change in the Austronesian world, pp. 377-386. Berlin: Mouton de Gruyter.

Prentice, John D. and Amir H. Usman. 1978. "Kerinci sound-changes and phonotactics", in: S.A. Wurm and Lois Carrington (eds), Second International Conference on Austronesian Linguistics; Fascicle I: Western Austronesian, pp. 121-163. Canberra: Department of Linguistics, Research School of Pacific Studies, Australian National University. [Pacific Linguistics C-61.]

Steinhauer, Hein and Amir H. Usman. 1978. "Notes on the morphemics of Kerinci (Sumatra)", in: Stephen A. Wurm and Lois Carrington (eds), 
Second International Conference on Austronesian Linguistics; Fascicle I: Western Austronesian, pp. 483-502. Canberra: Department of Linguistics, Research School of Pacific Studies, Australian National University. [Pacific Linguistics C-61.]

Steinhauer, Hein. 2002. “More (on) Kerinci sound-changes”, in: K. Alexander Adelaar and Robert Blust (eds), Between worlds; Linguistic papers in memory of David John Prentice, pp. 149-176. Canberra: Department of Linguistics, Research School of Pacific Studies, Australian National University. [Pacific Linguistics 529.]

Thomason, Sarah. G. 2001. Language contact; An introduction. Edinburgh: Edinburgh University Press.

Thomason, Sarah. G. 2006. Language change and language contact. Ann Arbor, MI: University of Michigan.

Thomason, Sarah. G. 2008. "Does language contact simplify grammars?". [University of Michigan; http:// www-personal.umich.edu/ thomason/ temp/simple2.pdf.]

Thomason, Sarah. G and Terrence Kaufman. 1988. Language contact, creolization, and genetic linguistics. Berkeley: University of California Press.

Trudgill, Peter. 1986. Dialects in contact, Oxford: Blackwell.

Trudgill, Peter. 2011. Sociolinguistic typology; Social determinants of linguistic complexity. Oxford: Oxford University Press.

Usman, Amir. H. 1976. Kamus umum Kerinci-Indonesia. Jakarta: Pusat Pembinaan dan Pengembangan Bahasa Departemen Pendidikan dan Kebudayaan R.I.

Usman, Amir. H 1988. Fonologi dan morfologi bahasa Kerinci dialek Sungai Penuh. $\mathrm{PhD}$ thesis, Universitas Indonesia.

Watson, C. W. 1984. Kerinci; Two historical studies. Cambridge: Centre of SouthEast Asian Studies, University of Kent at Canterbury.

Wurm, Stephen. A. 2003. “The language situation and language endangerment in the Greater Pacific area", in: M. Janse and S. Tol (eds), Language death and language maintenance; Theoretical, practical, and descriptive approaches, pp. 15-47. Amsterdam: John Benjamin. 